\title{
An Empirical Analysis of Policy Barriers Related to Trade Costs for Exporters
}

\author{
Shabana Noureen ${ }^{1}$ and Zafar Mahmood
}

\begin{abstract}
The trade costs imposed by numerous policy and non-policy barriers on exporters are still considered an impediment in their export growth rate. Thus, this paper aims to measure overyear trends in total trade costs and trends in trade costs related to policy barriers. Further, to find out which trade cost-policy barriers are high. The research found that total trade costs have a decreasing trend for the rest of the world while developing countries like Pakistan have the lowest rate of a declining trend. Trade cost estimates associated with tariff barriers show a declining trend, whereas trade costs related to non-tariff barriers are on the rise as compared to developed countries. The results further reveal that higher trade costs are among the major factors that have rendered especially developing countries' exports uncompetitive in world markets.
\end{abstract}

Keywords: Tariff Barriers, Non-Tariff Barriers, Policy Barriers, Trade Costs, Trade Policies, Trading Partners

JEL codes: F1, F10, F13, F14

\section{Introduction}

The economic size and factor endowment are not the only variables that define the trade capacity for countries. Trade strength also depends upon many other factors, including trade costs. Within the modern stream of international trade research, trade costs have drawn the

\footnotetext{
${ }^{1}$ Correspondence: shabana- noureen @s3h.nust.edu.pk.School of Social Sciences and Humanities (S3H), National University of Sciences \& Technology (NUST), Pakistan. Full list of author information is available at the end of the article.
} 
attention of international trade economists to explain the direction and trade volume between countries. Thus, trade costs have shown to be hazardous for economies incurring and reduce their potential volume of trade in the international market.

Along the same line, Samuelson (1954) claims that trade flows decrease by the same friction as melting an iceberg during passing through the sea. To capture an iceberg melting effect, the cost of trade between partner countries is measured. It is generally considered to comprise all the expenses to the point the product or services reach the end-user. On the other hand, according to Bernard et al. (2006) moving exportable commodities and final products to ports incur a huge cost and other risks. Baier and Bergstrand (2009) found that the increase in trade costs results in decreases in the volume of bilateral trade.

However, there is always a difference in the costs of trade in all countries. Largely this difference is due to the policy (tariff and non-tariff) barriers. Every country has different trade policy barriers that affect its costs of trade. To accelerate the growth of the economy for a country, it is imperative for reducing the trade costs associated especially with the policy barriers. Policy barriers associated with trade costs, such as tariffs, raise the price for consumers of imported goods, thereby discouraging the consumption of those goods. Saleem et al. (2014) also stated that increases the cost of both consumer goods and producer goods and depresses the economic benefits of competition, thereby inhibiting economic growth.

Further, Pomfret and Sourdin (2010) showed that trade costs associated with tariff barriers (TBs) are now at a historically low level in many countries, though total trade costs remain high. Marceau and Trachtman (2002) argued that international trade tariffs nowadays generally considered low, because of the liberalization, first in 1994 in the sponsorships of the General Agreement on Tariffs and Trade (GATT), the World Trade Organization (WTO) 
among member countries, and then under the regional and bilateral preferential trade agreements.

Consequently, after the agreement of WTO liberalization of bilateral and preferential trade policies have been originated and applied. Besides, only the tariff liberalization has confirmed unsuccessful for decreasing the overall trade costs. More attention should have been given to the trade costs associated with non-tariff barriers (NTBs), as they now the effects of the trade restriction represent major factors.

Trade costs associated with NTBs include mostly the trade policy-related cost, which happens from the start point of production right up to final consumer's revenue, with the exclusion of tariffs. Anderson and Wincoop (2004) stated that trade costs associated with NTBs included internal transport, customs, storage, port procedures, and marketing costs. Hoekman and Nicita (2008) argued that trade costs (especially associated with NTBs) are becoming a key negotiating field not alone for established economies then also for emerging economies. It is therefore important that especially developing countries are fully aware of the size and consequences of the trade costs associated with NTBs.

However, the rate of trade costs associated with NTBs in international trade has not been comprehended well. This is because the study of trade costs associated with NTBs did not keep up with their growing obstacles, leading to a knowledge gap. In this regard, the focus of the study is the quantification of trends in total trade costs for the bilateral trade of developing countries as an example of Pakistan. It may also investigate the Pakistani perspective in comparison with other partner countries.

Literature shows that Pakistan's economy has almost hit rock bottom due to the failure of the export sector (Khattak et al., 2011; Khan and Abasyn 2017 and Adams 2019). Pakistan's 
export growth since 2001 has been in proportion and synchronization with the tariff liberalization. According to GoP (2018), the tariff liberalization has been reversed by gradually increasing the applied tariff to $10.09 \%$; the exports declined by $19 \%$ to US\$ 20.4 billion since 2014. One of the major causes of the decline in exports was the increase in trade-related revenue through multiple layers of the TBs, NTBs, and other taxes of trade. Production of exports has been rendered less competitive internationally. As excessively employed, the TBs and NTBs of the trade costs have decreased competitiveness for the export industry by increasing the costs of inputs.

The fact is that exports to GDP ratio went down from $13.5 \%$ in 2010 to $8.2 \%$ in $2017^{2}$, reflects the impact of higher tariffs on exports. The regulatory duties have increased from 105 tariff lines in 2013 to over 1500 tariff lines in 2017. Currently, Pakistan maintains the thirdhighest average weighted tariff amongst the 68 countries having more than US\$20 billion annual exports. The customs duty and regulatory duties on raw materials, intermediate goods, and machinery are even higher. Like, the replacement of $0 \%$ duty slab, covering primarily the raw materials and machinery, with a $3 \%$ duty slab is adversely affecting the competitiveness of the manufacturing sector from 2014 to 2017.

The number of duty slabs further increased to 5\% in 2018 (GoP, 2018). To encourage exporters, a range of schemes is implemented to waive/refund import duties on their inputs; however, the advantages of such schemes could not be made use. As many exporters often fail to avail of the benefits of such exemption schemes or duty drawbacks, due to higher tariffs on raw materials and capital goods. Therefore, the trade costs associated with TBs and NTBs need to be examined and these policy barriers established leading to higher trade costs.

\footnotetext{
${ }^{2}$ Data is available at: https://databank.worldbank.org/source/world-development-indicators
} 
The present study attempts to fill the gap as a better understanding by quantifying the trade costs associated with TBs and NTBs. And identifying in rising costs of trade which policy barriers that lead to higher trade costs. Also, the study would provide an analysis of the implications of bilateral trade costs as it contains several areas that require particular attention.

In this study, a comparison is provided with competitor countries to quantify trade costs. It is going to the help of policymakers devise correct policy responses and to strengthen their capacity to conduct more efficient trade policies for the development of export-led growth. In the same way, the study will help to guide where they are needed the required technical and financial resources. Also, the current research could lead to a fairer international trade agreement. It may help to improve multilateral dialogue on policy issues related to trade costs.

The structure of this paper is as follows: Section 2 provides an overview of the relevant literature. Section 3 presents the methodology and source of data. Section 4 shows the empirical results and discussion. Section 5 concludes and provides policy implications of this work.

\section{Literature Review}

Economies consistently engage in trade across borders and face TBs, quotas, and other NTBs that constitute trade costs. These barriers include a lot of obstacles that limit the capability of a country for accessing the global markets.

How high a policy obstacle to trade costs for bilateral trade flows? This apparently simple question cannot be typically answered with accurateness, especially for developing countries. Different studies have analyzed trade costs policy barriers, but this contribution is minimal. The present study attempts to fill the gap as a better understanding by quantifying the trade costs associated with TBs and NTBs. And identifying in rising bilateral costs of trade 
which policy barriers that lead to higher trade costs especially for developing countries like Pakistan. Besides, the study would provide an analysis of the implications of bilateral trade costs as it contains several areas that require particular attention.

Ferrantino (2012) argued that the policy barriers along the supply chain developed hurdles for international trade. Following the observation of tariffs declining since the 1940s, he proposed that the government need to remove the restrictions of NTBs of trade costs. European Union partners most have declined their imports from developing countries due to greater NTBs. Stated by Bora et al. (2002), the developing world's economies are more riskprone to NTBs as these are largely concentrated in agriculture, garments, iron, steel, and textiles. Mostly these are top exporting products; therefore, trade of developing countries affected by them. Ferrantino (2012) said that NTBs might bear additional costs in meeting mandatory standards, for the case of an emerging world and could lead to market failures.

Although discussing the case of Pakistan, Saleem et al. (2014) study show that TBs for India and Pakistan are relatively higher. Trade barriers are the result of economic, military conflicts, and politics between these two countries. Pakistani exports encounter India's overwhelming implementation of NTBs, i.e. regulatory and security requirements that hinder Pakistani exports to India. According to Altaf et al. (2016), the United States is the top in the list for the enormous application of NTBs to Pakistani exports. Imposing NTBs most restricted the textile and clothing products in Pakistan.

In the empirical literature, Ardakani et al. (2000) use a gravity model for estimating the trade impact on the trade flow of TBs and NTBs levied from importers. Their study showed a negative effect of NTBs, affecting greater than that of TBs. Anderson and Wincoop (2004) surveyed and estimated costs of trade for developed countries to be around 170 percent of 
which costs of TBs were almost 44\%. Along the same line, De (2007) worked on the effect of costs on trade in Asian countries. He used the gravity model and found several trade cost components, including TBs, negatively and significantly influencing international trade patterns. In the same Vein, Kee et al. (2008) calculated an index of trade restrictiveness based on observed international TBs. They showed that tariffs represent a significant degree of trade costs. In a later work, Novy (2013) used the theory-based versions of the gravity model. He showed that NTBs affect international trade for the emerging world more than TBs.

The literature shows there is limited empirical research that documents the importance of trade cost covering the policy barriers particularly for developing countries. This is mainly because the data limitations make it difficult to document general trends in the preparation of trade cost and its policy barriers components like TBs and NTBs. Given the limitations in the available literature, it intends to contribute to the empirical literature, by analyzing the worldwide dataset to measure the trade costs associated with the policy barriers.

\section{Methodology}

This study measures the trade cost for 141 partner countries of trade for Pakistan for the period of 2003 to 2018. Trade costs associated with TBs and NTBs measures have provided in Appendix A. The present study derives a micro-founded model of bilateral costs of the trade from a theoretically based model of gravity, which circuitously deduces the frictions of the trade from perceived data. The gravity equation considered an important model for worldwide trade, as it links countries' bilateral trade to their economic size and bilateral trade costs.

Anderson and Wincoop (2004) described a micro-founded model of gravity, through the following exogenous bilateral trade costs:

$X_{i j}=\frac{Y_{i} Y_{j}}{Y^{w}}\left(\frac{t_{i j}}{\Pi_{i} p_{j}}\right)^{1-\sigma}$ 
where,

$X_{i j}$ represent the nominal exports of a country $i$ to $j, \frac{Y_{i} Y_{j}}{Y^{w}}$, denotes the income share for partner countries and $y^{w}$ is the world's income defined as $y^{w} \equiv \sum_{j} y_{j} \cdot\left(\frac{t_{i j}}{\Pi_{i} p_{j}}\right)^{1-\sigma}$ indicates the bilateral trade barriers of partner countries; $\sigma$ represents the elasticity of substitution for commodities. $\sigma>1$ represents the greater willingness of consumers to exchange for two products between them. $p_{j}$ and $\Pi_{i}$ are country j's and country $i$ 's price indices proxies for multilateral resistance variables, which indicate the barriers each country endures during trade with all their trading members and can be expressed as average costs of trade. $t_{i j}$ is symmetric bilateral costs of trade, which is the proxy for a distance. The assumption of symmetric trade costs means price indices $p_{j}$ and $\Pi_{i}$ are the same for both countries.

There is a range of disadvantages to this model, such as the selection of trade cost proxy of distance, which might be misspecified. This is a time-invariant proxy and it is not useful to capture the trade cost trends over time. The misspecified function of trade costs does not include the major components such as TBs and NTBs of related to trade costs, nor is it a theoretically dependent model of gravity for trade costs. The authors make the model simpler by assuming the trade costs as symmetric $\left(t_{i j}=t_{j i}\right)$. While bilateral trade costs are asymmetric like as compare to other countries if one country levies greater tariffs.

Keeping in mind the aforementioned disadvantages, this study follows a Novy (2013) approach that supports to resolve these shortcomings by developing an empirical model for calculating bilateral trade costs. This approach does not depend on any specific function of trade costs and does not enforce symmetry of trade costs. This method analytically solves a theoretical equation of gravity for parameters of exchange costs that identify obstacles to 
worldwide trade, like TBs and NTBs. It also indicates that a rise in bilateral trade obstacles affects not only national trade but also global trade. In this situation, certain products, the country 'i' used to buy locally (intra-nationally) are nowadays transported abroad. So this is not only the volume of global trade that relies on obstacles to trade with the remaining world but similarly the sum of intra-national commerce.

To obtain a bidirectional micro-founded theoretical based gravity equation, multiply Equation (1) with the opposite direction $\left(X_{j i}\right)$ for trade flow are given as follows:

$X_{i j} X_{j i}=\left(\frac{Y_{i} Y_{j}}{Y^{w}}\right)^{2}\left(\frac{t_{i j} t_{j i}}{\Pi_{i} p_{i} \Pi_{j} p_{j}}\right)^{(1-\sigma)}$

The same way domestic trade flows are:

$X_{i i} X_{j j}=\left(\frac{Y_{i} Y_{j}}{Y^{w}}\right)^{2}\left(\frac{t_{i i} t_{j j}}{\Pi_{i} p_{i} \Pi_{j} p_{j}}\right)^{(1-\sigma)}$

By dividing Equation (3) with Equation (2) we get

$\frac{X_{i j} X_{j i}}{X_{i i} X_{j j}}=\frac{\left(\frac{Y_{i} Y_{j}}{Y^{w}}\right)^{2}}{\left(\frac{Y_{i} Y_{j}}{Y^{w}}\right)^{2}} \frac{\left(\frac{t_{i j} t_{j i}}{\Pi_{i} p_{i} \Pi_{j} p_{j}}\right)^{(1-\sigma)}}{\left(\frac{t_{i i} t_{j j}}{\Pi_{i} p_{i} \Pi_{j} p_{j}}\right)^{(1-\sigma)}}$

Or,

$\frac{X_{i j} X_{j i}}{X_{i i} X_{j j}}=\left(\frac{\frac{t_{i j} t_{j i}}{\Pi_{i} p_{i} \Pi_{j} p_{j}}}{\frac{t_{i i} t_{j j}}{\Pi_{i} p_{i} \Pi_{j} p_{j}}}\right)^{(1-\sigma)}=\left(\frac{t_{i j} t_{j i}}{t_{i i} t_{j j}}\right)^{(1-\sigma)}$

By taking square-root (for the geometric average trade costs) and rearranging yields

$\left(\frac{t_{i j} t_{j i}}{t_{i i} t_{j j}}\right)^{\frac{1}{2}}=\left(\frac{X_{i i} X_{j j}}{X_{i j} X_{j i}}\right)^{\frac{1}{2(\sigma-1)}}$

As shipping costs can be asymmetric between $\mathrm{i}$ and $\mathrm{j},\left(t_{i j} \neq t_{j i}\right)$ represents as national costs of trade can vary crosswise countries. It is valuable to take the geometric average of the 
obstacles in both ways (which reveals the critical bidirectional tendency of barriers to exchange costs and help identify the impact of policy barriers). It is also beneficial to subtract one to get a look for the tariff equivalent in the fraction of the value of the goods to indicate bilateral costs of trade. The resultant measure for costs of trade is denoted as $\tau_{i j}$

$\tau_{i j} \equiv\left(\frac{t_{i j} t_{j i}}{t_{i i} t_{j j}}\right)^{\frac{1}{2}}-1=\left(\frac{X_{i i} X_{j j}}{X_{i j} X_{j i}}\right)^{\frac{1}{2(\sigma-1)}}-1$

where,

$\tau_{i j} \quad=$ Geometric average of trade cost between countries $i$ and $j$.

$t_{i j} t_{j i}=$ International (bilateral)trade cost from country $i$ to $j$ and $j$ to $i$.

$t_{i i} t_{j j}=$ Intranational (domestic) trade cost for country $i$ and $j$.

$X_{i j} X_{j i}=$ International (bilateral) trade flow from coutry $i$ to $j$ and $j$ to $i$.

$X_{i i} X_{j j}=$ Intranational (domestic) trade flow for country $i$ and $j$.

$\delta=$ Elasticity of substitution ( which is set $=8$, based on Novy (2013).

where $\tau_{i j}$ measures the bilaterally costs of trade, $t_{i j} t_{j i}$ indicate the relative costs of trade, domestically costs of trade represented by $t_{i i} t_{j j}$. Therefore, the estimates do not enforce national trade frictionless and capture what makes global trade more costly than national trade. It also calculates costs of trade in its broader sense, counting not only global costs of transport and tariffs TBs but also adds other elements for costs of trade addressed by Anderson and Wincoop research (2004). These include direct and indirect costs associated with language differences, currencies processes for import, and export. The elasticity of substitution set equivalent to 8 such as measured by Andorson and Wincoop (2004), which is the mid-range of 5 to 10 intended for the elasticity of substitution in all the calculations. 
The rationale is clear behind $\tau_{i j}$. If bilateral trade flow $X_{i j} X_{j i}$ increases relative to domestic trade flow $X_{i i} X_{j j}$. Trade between the two countries must become easier compared with domestic trade. This is taken by a reduction in $\tau_{i j}$ etc. Therefore, calculation measures economic costs indirectly by inferring them from measurable flows of exchange. Since these trading flows differ over time, not simply for cross-sectional data but similarly for panel and time-series data can be estimated for trading $\operatorname{costs} \tau_{i j}$. This is a benefit above the technique that Anderson and Wincoop (2004) have adopted which is used only cross-sectional data. This is also significant to emphasize that two-sided trade costs are considered as asymmetric $\left(t_{i j} \neq t_{j i}\right)$, instead of symmetric as measured by Anderson and Wincoop (2004) and that bilateral trade flows might be $\operatorname{unbalanced}\left(X_{i j} \neq X_{j i}\right)$.

\subsection{Bilateral Trade Costs Associated with TBs}

The bilateral trade costs associated with TBs is a measure of the tariffs levied by the two-member countries for each other's imports. The traditional trade models such as (Melitz 2003; Eaton and Kortum 2002 and Melitz and Ottaviano 2008) specifically explain that exporting countries have a greater number of exporters with large productive firms and goods sent to foreign markets. On the

other side, if exporting countries have high trade costs due to TBs, these measures forecast a decline in the total number of exporters, and hence several goods are exported. Nevertheless, they do not openly solve the problem of empirically measuring the extent of the effects of these policy barriers. This study empirically defines the bilateral costs associated with TBs as follow:

$\operatorname{GATTC}_{i j}=\sqrt{\left(1+\operatorname{tariff} f_{i j}\right)\left(1+\operatorname{tariff}_{j i}\right)}$

where, 


$$
\begin{aligned}
& \text { GATTC }_{i j}=\text { Bilateral geometric mean/average tariff trade cost. } \\
& \text { tarif } f_{i j}=\text { AHS dutiable tariff lines share (\%) imposed by country } i \text { on country } j . \\
& \text { tariff } f_{j i}=\text { AHS dutiable tariff lines share (\%) imposed by country } j \text { on country } i .
\end{aligned}
$$

The TBs related to trade costs are calculated using effectively applied (AHS) dutiable tariff lines percentage share for all products. The calculation of this rate takes into consideration the categories in which tariffs are essentially imposed and disregards all other categories in which the tariffs are set to zero. Presently, this model would provide a greater estimation of average tariffs than the maximum of the other estimates as several countries have various categories of products with zero tariffs imposed.

The simple average tariffs exaggerate the degree of trade costs if a nation has the majority of its trade in a rare category with the zero tariffs, but has greater tariffs in many other import categories where imports would not ever be valuable. By using a weighted average tariff this issue can be ignored to some degree. Like, supposing a nation has comparatively minimum trade because it has excessive tariffs (i.e. as to eliminate imports set higher tariffs) in several categories, then for such a highly protectionist country, a low tariff trade cost could be reported. It can also be noted that the simple average tariff would, in this case, record higher tariff trade costs. Using the regular tariff rate at dutiable imports for all products is the best way to exaggerate the level of tariff exchange costs.

Such as for the year 2018 Pakistan impose tariff on China's products are $62.12 \%$, while China impose tariff on Pakistan's products are 67.73\%. Thus, the bilateral tariff trade cost is $\sqrt{(1+0.6212)(1+0.6773)}=1.6490$. Stated in ad valorem equivalent method, the 
geometric mean/average bilateral tariff levied by Pakistan and China is $(1.6490-1)=64.86 \%$ (see Table 2).

\subsection{Bilateral Trade Costs Associated with NTBs}

Trade costs associated with NTBs are not easy to define. Their measurement is a multifaceted task that is faced with specific quantitative restrictions and limited accessibility of the data. To overcome this problem, by following Anderson and Wincoop (2004), this research analyzes the bilateral costs of trade associated with NTBs, which includes all other costs except tariffs for trading goods as follows:

$\mathrm{NTC}_{\mathrm{ij}}=\left(\left(\frac{1+\left({ }^{\mathrm{t}_{\mathrm{ij}}} / 100\right)}{\mathrm{GATTC}_{\mathrm{ij}}}\right)-1\right) \times 100$

where,

$$
\begin{aligned}
& N T C_{i j}=\text { trade cost associated with NTBs. } \\
& t_{i j} \quad=\text { Bilateral trade cost. } \\
& \text { GATTC }_{i j}=\text { Geometric mean or average tariff trade costs. }
\end{aligned}
$$

Like total trade cost between Pakistan-China in 2018 is 2.263952 (while in ad valorem equivalent form it is 126.39521) and geometric mean or average bilateral tariff cost is 1.0756575 . Then nontariff trade cost without tariff trade cost is $((2.263952 / 1.0756575)-1) * 100=110.47 \%$ (see Table 3). This measure of non-tariff trade cost is best applicable as this research more focus on to facilitate the exporters for their export.

\section{Results and Discussion}

\subsection{Total Trade Costs}

The countries for which trade costs can be estimated in the sample for all years were only considered for analysis. Table 1 represents that the trend in the costs of trade is declining and this 
trend is fairly steady worldwide. Results show that a steady historical reduction in the costs of trade trend stayed undoubtedly one of the main reasons for the rise of worldwide trade flows to the extent that almost every country trades more today than it did decades ago.

The findings revealed the growth rate of world trade increases because of the decline in the costs of trade. The declining trend in trade costs for Pakistan is comparatively low compared to the world. The trade cost values are calculated in ad valorem equivalents. The total value of the trade cost indicators varies greatly, including in ad valorem form, depending on the underlying assumptions regarding the value of the elasticity of substitution. ${ }^{3}$ This estimated trade cost should therefore ideally be used for comparative analysis or to analyze changes in trade costs over time.

In 2003, the ad valorem equivalent trade cost for all trading goods between Pakistan and partner countries was $274 \%$ (see Table 1). It indicates that, on average, trade in goods between Pakistan and the partner countries concerned for all tradable goods imposes an additional cost of approximately $274 \%$ of the value of the goods when Pakistan trade these goods within its borders.

Table 1 show that the difference of decreasing trend in the costs of trade for Pakistan in comparison to the world as a whole was almost $40 \%$ less in 2003. This gap of a trend instead of decreasing became larger to around $67 \%$ in 2018 . Results show that variance in the rate of this declining trend of trade costs in comparison to developed countries is also lower, as in 2003 for the United States, the United Kingdom, and Germany it was $131 \%, 127 \%$, and $105 \%$ respectively lower. In 2018, it increased to approximately $156 \%, 150 \%$, and $127 \%$ respectively for the same countries, which are correspondingly higher amounts.

Further, In comparison with emerging countries such as India and China, the gap of the rate in declining trend of trade costs for 2003 was almost $49 \%$ and $87 \%$ respectively lower. In 2018 ,

\footnotetext{
${ }^{3}$ Based on the literature review the elasticity of substitution set equal to 8. See Jacks et al. (2008) for more details.
} 
the gap in declining trend steadily increased by $74 \%$ and $115 \%$ respectively. The country's relative position is, nonetheless, deteriorating because the reduction in the costs of trade for the rest of the world is faster than Pakistan (Table 1).

Table 1 Average Bilateral Trade Costs for World, Pakistan, India, China, USA, UK and Germany

\begin{tabular}{|c|c|c|c|c|c|c|c|}
\hline Year & World & Pakistan & India & China & USA & UK & Germany \\
\hline 2003 & 234 & 274 & 209 & 171 & 143 & 147 & 169 \\
\hline 2004 & 233 & 274 & 209 & 170 & 143 & 147 & 168 \\
\hline 2005 & 233 & 273 & 207 & 169 & 142 & 146 & 168 \\
\hline 2006 & 232 & 272 & 207 & 168 & 142 & 145 & 167 \\
\hline 2007 & 228 & 271 & 205 & 166 & 141 & 145 & 166 \\
\hline 2008 & 225 & 269 & 205 & 166 & 139 & 144 & 164 \\
\hline 2009 & 223 & 268 & 202 & 164 & 136 & 142 & 161 \\
\hline 2010 & 222 & 266 & 201 & 163 & 133 & 138 & 157 \\
\hline 2011 & 221 & 266 & 201 & 162 & 129 & 137 & 154 \\
\hline 2012 & 215 & 265 & 200 & 159 & 126 & 134 & 150 \\
\hline 2013 & 211 & 263 & 197 & 158 & 122 & 129 & 148 \\
\hline 2014 & 203 & 260 & 193 & 155 & 118 & 126 & 144 \\
\hline 2015 & 201 & 260 & 190 & 151 & 113 & 117 & 140 \\
\hline 2016 & 198 & 259 & 187 & 148 & 111 & 113 & 135 \\
\hline 2017 & 195 & 259 & 185 & 144 & 108 & 111 & 133 \\
\hline 2018 & 191 & 258 & 184 & 143 & 102 & 108 & 131 \\
\hline
\end{tabular}

Source: Author's calculations.

Note: The costs of trade are estimated in ad valorem equivalent form. 
This decline of trade costs with small tendencies because of the trade restrictions, political uncertainty, and strict procedures for licensing permits, fluctuations in global economic policies such as trade protectionism and visa hassles (Kee et al., 2008). There are also many other factors behind the less decreasing trade costs trend; includes less trade liberalization, currency restrictions, minimum trade facilitation, scarce energy supplies, and no corporate taxation. Technological factors are also responsible for Pakistan's slow declining trend of trade costs compared with other partner countries.

The net result for higher trade costs is a decline in the export flows of Pakistan to the international markets. As the declining trends of trade costs become smaller (Table 1), in the same way, exports lead to negative growth. This negative growth or decline in exports was reached to around $12.4 \%$ for the FY 2014-2016 (GoP, 2018). Such as not enough attention is paid to the issue of trade cost shows the inability of Pakistan to export its potential from the last two decades. Since the government's lack of support in terms of regulations, legislation, and institutional support, etc., hurts further export growth.

Figure 1 also show empirical facts in the support of Pakistan's low export share to partner countries because of the higher costs of trade. As a first look at the data, Figure 1 represents that the export share more than 70 to $80 \%$ was going to limited partner countries (China, UK, USA, U.A.E, Bangladesh, Afghanistan, Spain, Germany, France, and Italy) due to the different size of their costs of trade. 


\section{Figure 1 Export Partner Share and Bilateral Trade Costs of Pakistan}

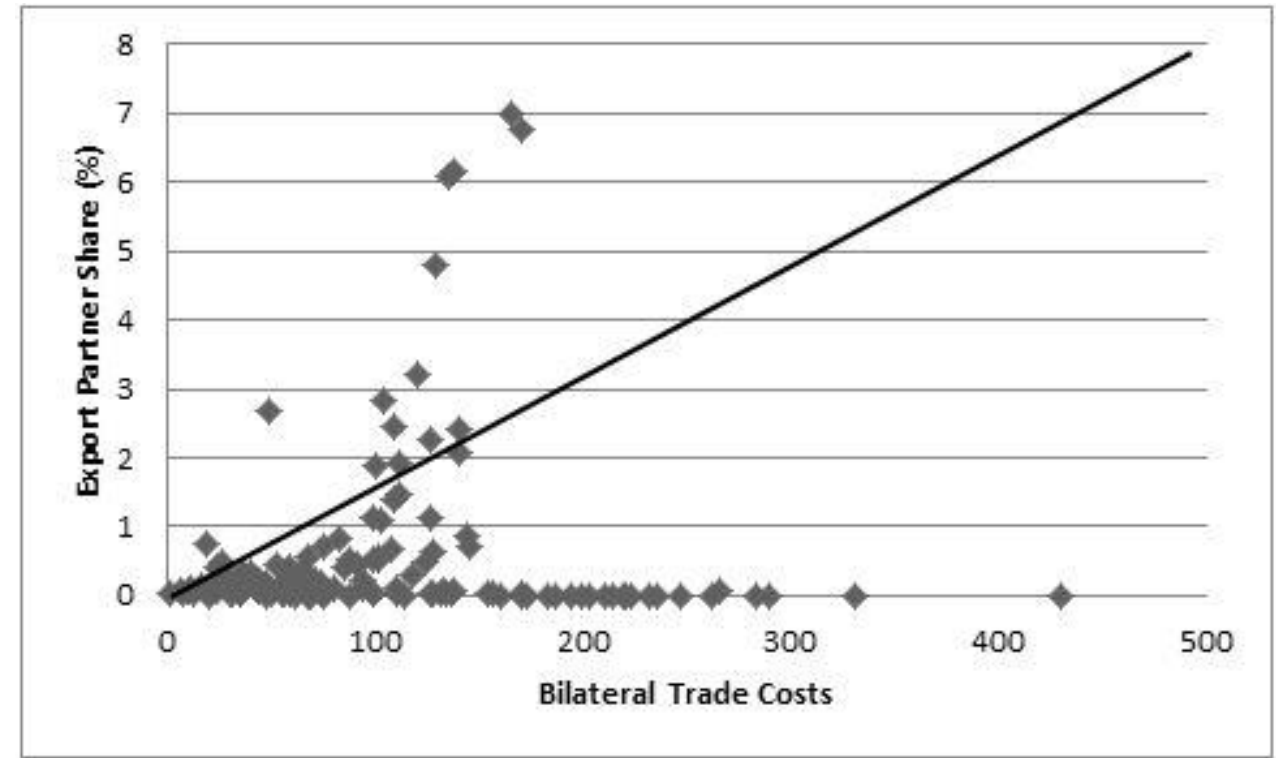

Source: Author's calculations, export's share data taken from WITS.

Therefore the difference in the costs of trade for different countries accounts for the difference in the share of exports to them. This suggests that merchandise goods are not exported more to those partners with them trade costs are large, it holds for a large range of countries. For that, one can see that maximum export share to partner countries are below the forty-five-degree line in Figure 1. This indicates that higher trade costs lower down the speed of exports growing in Pakistan. This empirical fact is consistent with a greater number of studies in the literature for the trade costs, which also finds that export has been seen on the continuous decline because of the imposition of large trade costs (Brenton et al., 2001; De, 2007 and Were 2014).

In these conditions, creating a structure and guidelines to assist and reduce the costs of trade faced by their exporters is a policy challenge. Only then it will be in a position to participate efficiently in the global value chain and supply for long-term development. As lower and more competitive trade costs encourage the countries to move up in the global value chains 
(GVCs). Therefore, a need for the adoption of efficient trade policies is essential for the future faster decline of trade costs and to promote international trade.

\subsection{Costs of Trade Associated with Policy Barriers}

\subsubsection{Trade Costs Associated with TBs}

In the quantification of trade costs associated with TBs for Pakistani exporters levied by partner countries, Table 2 shows the declining trend. Results show that the extent of this decreasing tariff trade cost becomes less, when compared from the year 2003 to 2018 for developed partner countries. The declining trend in developed partner countries likes for the United States, the United Kingdom, and Germany in 2003 was nearly $12.86 \%, 71.01 \%$, and $65.35 \%$ respectively. This trend decreased, but with a small proportion in 2018 , nearly $11.89 \%, 66.45 \%$, and $64.74 \%$ respectively. Pakistan's three largest trading partners are not regional neighbors, but they represent its relatively large export markets. GSP+ status allows Pakistan duty-free access to the European market at zero tariffs and preferential rates of $70 \%$. A declining trend in trade costs associated with TBs, but with a small proportion gives a way of thinking in promoting further bilateral free trade agreements and liberalizing trade with them.

Table 2 reflects, in comparison with developing partners like China, India, Afghanistan, Sri Lanka, and Bangladesh, trade costs associated with TBs trends are also falling with more rates. The decline rate of the costs related to TBs for these countries was around $63.52 \%$, $59.06 \%, 62.34 \%, 65.24 \%$, and $58.29 \%$ respectively in 2003 . This trend is more declining at $68.57 \%, 65.48 \%, 64.02 \%, 67.98 \%$ and $61.76 \%$ respectively in 2018 .

This is because the maximum standard tariff rate for developing partner countries was also reduced after becoming a member of the South Asian Association for Regional Cooperation (SAARC) and the Economic Cooperation Organization (ECO). Successive rounds 
of multilateral trade negotiations have also helped to bring about substantial reductions in trade costs associated with TBs.

Multilateral negotiations under WTO auspices have brought tariffs down to historic lows for Pakistan in the last two decades. Goods tariffs were also lowered during the eight rounds of WTO and GATT negotiations. The free trade agreements (FTAs) with developing partner countries include the removal of Pakistan's quotas, tariffs and other barriers to international trade. Pakistan has signed various FTAs and preferential trade agreements (PTAs) with its developing trade partners. Such as, in the South Asian region, since June 2005 Pakistan has FTA with Sri Lanka. Under this FTA Pakistani exporters enjoy duty-free market access in the Sri Lankan. The FTA between China and Pakistan was also approved in 2006. Under this FTA tariff on Pakistani exports to China, $50 \%$ of the product lines have been removed. Pakistan and Malaysia signed FTA in 2007, whereby Malaysia abolished tariffs for imports from Pakistan by nearly $78 \%{ }^{4}$.

Similarly, Pakistan has also a PTA with Iran and Mauritius. The Pakistan-Mauritius PTA was signed in 2007, in which Mauritius granted tariff concessions on 102 Pakistani products/items. Iran in its PTA offered Pakistan tariff concessions on 309 tariff lines. Likewise, the South Asian Free Trade Area (SAFTA) is yet another important trade agreement between Pakistan and several other South Asian countries formed in 2006. Nonetheless, Pakistan was not very successful in exploring the full potential of these trade agreements because of poor trade policies and less responsive in reducing its costs of trade.

\footnotetext{
${ }^{4}$ See for more detail, ministery of commerance . Available at: http://www.commerce.gov.pk/
} 
Table 2 Average Bilateral Tariff Barriers Trade Costs of Pakistan with World and Major Partner Countries

\begin{tabular}{|c|c|c|c|c|c|c|c|c|c|}
\hline Year & World & USA & UK & Germany & China & Afghanistan & India & $\begin{array}{c}\text { Sri } \\
\text { Lanka }\end{array}$ & $\begin{array}{c}\text { Bangla } \\
\text { desh }\end{array}$ \\
\hline 2003 & 79.25 & 66.39 & 8.24 & 13.90 & 15.73 & 16.91 & 20.19 & 14.01 & 20.96 \\
\hline 2004 & 79.02 & 62.84 & 8.04 & 12.84 & 11.82 & 15.81 & 20.76 & 14.27 & 19.64 \\
\hline 2005 & 84.12 & 63.50 & 9.35 & 12.69 & 9.81 & 13.83 & 15.40 & 14.33 & 17.41 \\
\hline 2006 & 82.54 & 62.37 & 9.45 & 10.69 & 9.74 & 11.49 & 15.41 & 10.80 & 18.68 \\
\hline 2007 & 82.28 & 62.80 & 9.29 & 9.62 & 8.91 & 10.38 & 14.83 & 9.53 & 17.85 \\
\hline 2008 & 79.81 & 61.62 & 8.80 & 9.58 & 8.59 & 10.23 & 14.40 & 7.84 & 16.35 \\
\hline 2009 & 79.36 & 61.40 & 9.26 & 9.54 & 8.21 & 10.18 & 11.14 & 12.31 & 17.82 \\
\hline 2010 & 76.97 & 60.77 & 9.20 & 9.51 & 7.53 & 9.87 & 8.61 & 10.54 & 17.29 \\
\hline 2011 & 6.29 & 60.41 & 9.51 & 9.50 & 7.33 & 9.64 & 7.40 & 5.00 & 17.97 \\
\hline 2012 & 75.28 & 60.65 & 9.18 & 8.89 & 6.56 & 9.59 & 7.73 & 5.85 & 18.04 \\
\hline 2013 & 75.75 & 60.08 & 9.20 & 8.88 & 5.89 & 9.59 & 13.12 & 10.23 & 17.61 \\
\hline 2014 & 73.64 & 62.13 & 7.70 & 8.83 & 5.60 & 9.48 & 11.13 & 4.34 & 14.32 \\
\hline 2015 & 75.33 & 62.36 & 7.10 & 8.83 & 5.24 & 9.42 & 10.69 & 3.48 & 10.39 \\
\hline 2016 & 74.77 & 61.83 & 7.00 & 8.72 & 5.19 & 9.42 & 7.59 & 3.60 & 11.22 \\
\hline 2017 & 73.23 & 63.15 & 6.89 & 8.71 & 5.17 & 9.41 & 7.62 & 5.06 & 11.22 \\
\hline 2018 & 73.43 & 61.54 & 6.98 & 8.69 & 4.86 & 9.41 & 7.95 & 5.45 & 11.67 \\
\hline
\end{tabular}

Source: Author's calculation.

Note: The trade costs are estimated in ad valorem equivalent form. 
Exports, however, do not flow freely between partner countries, even among those with excellent relations in Pakistan. Still, the potential benefits of further reducing the barrier to partner countries in Pakistan are important. Table 2 results show that greater export flows could occur, especially among neighboring countries if tariffs for all Pakistani products are more liberalized.

\subsubsection{Trade Costs Associated with NTBS}

Between 2003 and 2018, the increase in trade costs associated with NTBs for Pakistan is rising. Table 3 illustrates this growing trend with world and also with its major partners. Results indicate that these trade cost trends are more or greater than Pakistan's trade costs associated with TBs and vary enormously across its partners. This reflects trade costs associated with NTBs restricted the increasing trade flows with partners.

Another important finding from this study is that the rate of growing trends in trade costs associated with NTBs to developed countries is greater than that of emerging countries. For example, developed members; the United States, the United Kingdom, and Germany showed an increasing trend in trade costs associated with NTBs around 45.55\%, 45.77.8\%, and $44.05 \%$ respectively in 2003 . While this trend rises in a higher proportion in 2018 , for the same partner countries, approximately $112.42 \%, 112 \%$, and $100.14 \%$ respectively.

In developing countries like China, India, Afghanistan, Sri Lanka, and Bangladesh, the rising trend in trade costs related to NTBs was around $39.36 \%, 16.32 \%, 86.75 \%, 55.01 \%$, and $47.33 \%$, respectively. In 2018, this rising trend rate increased to almost $115.86 \%, 90.21 \%$, $127.46 \%, 84.6 \%$ and $107.34 \%$ respectively. 
Table 3 Average Bilateral Non-Tariff Barriers Trade costs of Pakistan with World and Major Trading Partner Countries

\begin{tabular}{lllllllllll}
\hline Year World & USA & UK & Germany & China & Afghanistan & India & Sri & Bangladesh \\
& & & & & & & & Lanka & \\
\hline 2003 & 152.84 & 107.29 & 107.07 & 108.79 & 113.48 & 66.09 & 136.52 & 97.83 & 105.51 \\
2004 & 156.58 & 108.10 & 106.74 & 110.71 & 113.76 & 66.31 & 122.05 & 97.84 & 106.17 \\
2005 & 177.41 & 109.11 & 103.11 & 113.08 & 109.40 & 66.77 & 114.84 & 95.88 & 102.17 \\
2006 & 190.30 & 99.26 & 106.49 & 116.32 & 109.51 & 67.02 & 107.60 & 99.39 & 106.60 \\
2007 & 198.76 & 103.64 & 114.41 & 116.55 & 112.14 & 67.63 & 113.06 & 104.46 & 103.02 \\
2008 & 201.67 & 109.09 & 116.84 & 116.81 & 119.73 & 68.81 & 112.34 & 114.06 & 107.59 \\
2009 & 204.46 & 109.80 & 112.96 & 119.57 & 111.40 & 72.29 & 127.35 & 109.39 & 109.56 \\
2010 & 206.06 & 107.87 & 109.83 & 119.75 & 105.85 & 80.21 & 128.56 & 114.44 & 100.96 \\
2011 & 212.53 & 112.57 & 109.26 & 120.57 & 111.27 & 77.62 & 142.40 & 126.34 & 98.81 \\
2012 & 213.11 & 122.41 & 112.42 & 122.89 & 106.06 & 86.45 & 139.19 & 126.22 & 107.73 \\
2013 & 214.07 & 120.22 & 111.29 & 123.44 & 100.33 & 89.29 & 117.87 & 115.88 & 113.11 \\
2014 & 216.13 & 124.49 & 113.38 & 124.53 & 106.22 & 85.38 & 124.69 & 143.29 & 124.50 \\
2015 & 217.45 & 122.81 & 119.00 & 124.94 & 107.66 & 78.78 & 133.24 & 147.84 & 137.92 \\
2016 & 218.38 & 121.98 & 114.90 & 125.21 & 109.13 & 77.49 & 142.03 & 150.75 & 117.95 \\
2017 & 221.10 & 117.57 & 116.12 & 126.15 & 112.17 & 95.84 & 144.53 & 144.24 & 118.97 \\
\hline 2018 & 226.33 & 113.91 & 114.33 & 126.19 & 110.47 & 98.87 & 136.12 & 141.73 & 118.99 \\
\hline & & & & & & & & \\
\hline
\end{tabular}

Source: Author's calculation.

Note: The trade costs are estimated in ad valorem equivalent form. 
Because of poor connectivity, less trade facilitation, less favorable concessional arrangements, and a strict security paradigm, trade costs related to NTBs are becoming a major challenge for Pakistan and raising the price of its exported goods particularly for the countries of neighboring partners.

Higher trade costs related to NTBs, not lone cost Pakistan global trade, but similarly demonstrate that the major achievements of Pakistan's bilateral FTAs, RTAs, and liberalization of the economy have not fully achieved trade gains. This growing trend in trade costs associated with NTBs further raise trade costs and likely diminishes Pakistan's opportunities for new trade and investment. Pakistan frequently struggles to access international markets due to greater costs of policy constraints particularly related to NTBs. Policy initiatives that go well beyond the limits of the conventional trade policy need to be addressed. There is a need for a policy framework that involves reducing the trade costs associated with NTBs.

\section{Conclusion}

This study aims to quantify trends in total trade costs, to find out the trend in bilateral trade costs and whether developing countries like Pakistan has experienced higher or lower costs compared to other partner countries and the world as a whole. And to analyze estimates of the trend in the costs of trade over the years related to policy barriers (such as TBs and NTBs). To quantify the costs of trade-related to TBs and NTBs and to find out which trade cost policy barriers are large. The empirical analysis was shown using trade data for 141 trading partners for the period 2003-2018.

Empirical results show that, compared to other countries in the world, Pakistan has the lowest rate of a declining trend in total trade costs. Trade costs are declining with small trends due to trade restrictions, political uncertainty, and restrictive licensing procedures and visa 
difficulties. These also act as a barrier to the export of products, since most of the inputs to produce exported goods are imported only through designated ports and roads, the restricted number of export commodities, etc. It indicates that there is still substantial room to further lower them.

The consequences of a continuously increasing pattern of costs of trade associated with NTBs are also an essential cause of why the costs of trade mainly for developing countries remain stubbornly higher. The empirical conclusion is that trade costs associated with NTBs greater or more than Pakistan's TBs related trade costs, especially with developing countries. As a result, economies can forego opportunities to engage in global trade if exporters decide that the cost of meeting additional market requirements is too high. The policy barriers become the key constraints, particularly for exporters.

\subsection{Policy Implications}

The success of trade liberalization depends heavily on the ability to control trade costs, particularly in terms of the NTBs imposed costs on exporters. In the same way, quotas, prohibitions, export taxes, marketing costs, port processes, internal transport processes, storage, and other voluntary export restrictions are enforced at the border, i.e. for goods entering or exiting the State. Nonetheless, this needs an innovative policy response in line with current trade facilitation trends, effective border clearing procedures, etc. In this regard, the principles that should guide regulatory practices are as follows:

- Policymakers should remove these trade costs using clear rules and should urge all member countries to reduce trade costs associated with TBs and NTBs by developing their bilateral, multilateral, and FTAs. 
- There are currently numerous efforts being made to facilitate trade at national, international, and multilateral forums. Developing countries needs to take an active part in these efforts to benefit from changing global trade patterns. Two current initiatives are the WTO's trade facilitation agreement (TFA), and the US-led mega trading blocks in Asia and Europe (Trans-Pacific Partnership and Transatlantic Trade and Investment Partnership agreements). Active engagement in these programs could expand the developing economies like Pakistan by promoting export-oriented organizations and lowering the trade cost of policy barriers.

- For reducing the trade costs associated with NTBs, the partner countries should avoid using rules which limit exports. They should redesign procedural verification compliance and other paper transactions between administrations and producers or suppliers, thereby reducing red tape. Effective measures must be taken by the custom dealings, reducing port inefficiencies, revamping internal connectivity, reducing corruption, and enhancing other trade-related institutional and socio-political factors. Such policy regulatory measures among trading partners have the power not only to minimize the trading costs but also to modernize administrative operations.

- Trade costs can be reduced by dialog and information exchange with partner countries. The government should create a standing task force that periodically analyses changes in partner countries ' trade policies, assesses the effect of those policies on reducing trade costs, and reacts in real-time with counter-policy interests in reducing trade costs. In this way, regulators become another important tool for international collaboration to raise trade costs. 
These principles constitute a long-term goal for developing countries like Pakistan to reduce the bilateral trade costs. The above regulation of government policy reforms suggests a way for the central role among trading partner countries.

\section{Funding}

This research did not receive any specific grant from funding agencies in the public, commercial, or not-for-profit sectors.

\section{Authors' contributions}

Shabana Noureen is the main author of the manuscript; she undertook the literature review, developed the theoretical framework, collected and analyzed the data from the different sources. Zafar Mahmood is a co-author of this manuscript; he approved the research idea, supported the empirical data analysis, and gave suggestions and comments. Both authors read and approved the final manuscript.

\section{Authors' information}

Shabana Noureen is a PhD student at the department of economics, School of Social Sciences and Humanities (S3H), National University of Sciences \& Technology (NUST) Islamabad 44000, Pakistan. ORCID Id: https://orcid.org/0000-0002-7699-6647, shabana- noureen@s3h.nust.edu.pk.

Zafar Mahmood, is a full-time professor and doctoral supervisor at the School of Social Sciences and Humanities, National University of Sciences and Technology (NUST), Islamabad, Sector H-12, Pakistan. Email: dr.zafar@s3h.nust.edu.pk.

\section{Availability of data and materials}

Intra-national trade flows (domestic output minus exports) data have been collected from EU Klems (capital, labor, energy, materials, and service), OECD (Organization for Economic Co-operation and Development) STAN (Structural Analysis Statistics), OECD I/O (Input/ Output) tables, UN-ESCAP (United Nations Economic and Social Commission for Asia and the Pacific), Trading Across Borders Data, WDI (World Development Indicators), Direction of Trade Statistics and complemented with national data.

Data for international trade flows have been collected from OECD ITCS (International Trade by Commodity Statistics), UN COMTRADE, whereas the bilateral tariffs data have been obtained from WITS (World Integrated Trade Solution), WTO (World Trade Organization) and UNCTAD (United Nations Conference on Trade and 
Development) TRAINS (Trade Analysis Information System). Linear interpolation has been used to fill in the missing observations.

\section{Competing interests}

The authors declare that they have no competing interests.

Acknowledgement: Not applicable.

\section{Author details}

School of Social Sciences and Humanities (S3H). National University of Sciences \& Technology (NUST) Islamabad 44000, Pakistan.

\section{References}

Adams, J. Q. (2019). Exports, Politics, and Economic Development: Pakistan, 1970-1982. Routledge.

Altaf, S., Mahmood, Z., \&Noureen, S. (2016). Trade costs of Pakistan with its major trading partners: Measurement and its determinants. NUST Journal of Social Sciences and Humanities, 3(2), 1-32.

Anderson, J. E., \& Van Wincoop, E. (2004). Trade costs. Journal of Economic Literature, 42(3), 691-751.

Ardakani, Z., Yazdani, S., \&Gilanpour, O. (2009). Studying the effects of Non-Tariff Barriers on the export of the main agricultural products of Iran. American Journal of Applied Sciences, 6(7), 1321-1326.

Arvis, J. F., Duval, Y., Shepherd, B., \&Utoktham, C. (2013). Trade costs in the developing world: 1995-2010.Asia-Pacific Research and Training Network on Trade (ARTNeT), Bangkok.

Baier, S. L., \&Bergstrand, J. H. (2009). Bonus Vetus OLS: A simple method for approximating international trade-cost effects using the gravity equation. Journal of International Economics, 77(1), 77-85. 
Bernard, A. B., Jensen, J. B., \& Schott, P. K. (2006). Trade costs, firms and productivity. Journal of Monetary Economics, 53(5), 917-937.

Bora, B., Kuwahara, A., \& Laird, S. (2002). Quantification of non-tariff measures.UNCTAD Study Series, (18).United Nations Publications.

Brenton, P., Sheehy, J., \&Vancauteren, M. (2001). Technical barriers to trade in the European Union: importance for accession countries. JCMS: Journal of Common Market Studies, 39(2), 265-284.

De, P. (2007). Impact of trade costs on trade: Empirical evidence from Asian countries (No. 27). Asia-Pacific Research and Training Network on Trade (ARTNeT), Bangkok.

Eaton, J., \&Kortum, S. (2002). Technology, geography, and trade. Econometrica, 70(5), 1741-1779.

Ederington, J., \&Ruta, M. (2016). Non-tariff measures and the world trading system.The World Bank.

Ferrantino, M. J. (2012). Using supply chain analysis to examine the costs of non-tariff measures (NTMs) and the benefits of trade facilitation. WTO Staff Working Paper, No. ERSD-2012-02, World Trade Organization (WTO), Geneva.

Ferraz, L. P. D. C., \&Ribeiro, M. B. (2018). New Tools for the CGE Analysis of PTAs in the era of Non-Tariff Barriers and Global Value Chains: The Case of Mercosur and China. RevistaBrasileira de Economia, 72(3), 330-360.

GoP (2018).“Pakistan Economic Survey”. Finance Division, Government of Pakistan.

GoP (Various Issues)."Pakistan Economic Survey”. Finance Division, Government of Pakistan. 
Hamid, N. and S. Hayat (2012) The opportunities and pitfalls of Pakistan's trade with China and other Neighbours. The Lahore Journal of Economics, 17 (4), 271-292.

Jacks, D. S., Meissner, C. M., \& Novy, D. (2008). Trade Costs, 1870-2000. American Economic Review, 98(2), 529-34.

Khan, M., \& Abasyn, J. (2017). An exploratory evidence of the types of challenges and opportunities perceived by the Small and Medium Enterprises (SMEs) in the apparel export sector of Pakistan. University Journal of Social Sciences, 10(2), 373-395.

Khattak, J. K., Arslan, M., \& Umair, M. (2011). SMEs' export problems in Pakistan. E3 Journal of Business Management and Economics, 2(5), 192-199.

Kee, L. H., Nicita, A., \&Olarreaga, M. (2008).Estimating trade restrictiveness indices. The Economic Journal, 119(534), 172-199.

Marceau, G., \&Trachtman, J. P. (2002). The Technical Barriers to Trade Agreement, the Sanitary and Phytosanitary Measures Agreement, and the General Agreement on Tariffs and Trade A Map of the World Trade Organization Law of Domestic Regulation of Goods. Journal of World Trade, 36(5), 811-881.

Melitz, M. J. (2003). The impact of trade on intra-industry reallocations and aggregate industry productivity. Econometrica, 71(6), 1695-1725.

Melitz, M. J., \&Ottaviano, G. I. (2008).Market size, trade, and productivity. The Review of Economic Studies, 75(1), 295-316.

Novy, D. (2013). Gravity redux: measuring international trade costs with panel data. The Western Economic Journal, 51(1), 101-121.

Pomfret, R., \&Sourdin, P. (2010). Why do trade costs vary? Review of World Economics, 146(4), 709-730. 
Saleem, N., Jabeen, S., Omer, S., and Hanan, M.A. (2014) Indo-Pakistan trade relations: A critical discourse: Analysis of Daily Dawn. South Asian Studies, 29(1): 309-320.

Samuelson, P. A. (1954). The transfer problem and transport costs, II: Analysis of effects of trade impediments. The Economic Journal, 64(254), 264-289.

Suranovic, S. (2010). International trade: Theory and policy.

Were, M. (2015). Differential effects of trade on economic growth and investment: A crosscountry empirical investigation. Journal of African trade, 2(1), 71-85. 


\begin{tabular}{|c|c|c|c|c|}
\hline Sr. No & Partner Countries & $\begin{array}{l}\text { Total Trade } \\
\text { Costs }\end{array}$ & $\begin{array}{l}\text { Tariff Trade } \\
\text { Costs }\end{array}$ & $\begin{array}{l}\text { Non-Tariff } \\
\text { Trade Costs }\end{array}$ \\
\hline 1 & Afghanistan & 170.961 & 14.68167 & 122.4316 \\
\hline 2 & Algeria & 94.11692 & 6.243329 & 79.61848 \\
\hline 3 & Angola & 266.0625 & 14.07962 & 134.6374 \\
\hline 4 & Argentina & 58.1691 & 8.752449 & 39.65365 \\
\hline 5 & Armenia & 331.4433 & 16.73657 & 341.9217 \\
\hline 6 & Austria & 53.8109 & 16.88966 & 16.74214 \\
\hline 7 & Azerbaijan & 71.04378 & 13.63303 & 93.22906 \\
\hline 8 & Bahrain & 108.9848 & 14.59795 & 66.61136 \\
\hline 9 & Bangladesh & 118.8821 & 12.36075 & 90.47015 \\
\hline 10 & Barbados & 195.1223 & 11.50377 & 184.2244 \\
\hline 11 & Belarus & 21.10932 & 11.56256 & 36.8993 \\
\hline 12 & Belgium & 141.0213 & 16.55838 & 94.5618 \\
\hline 13 & Benin & 40.47365 & 12.13866 & 16.08781 \\
\hline 14 & Bolivia & 183.3172 & 13.26315 & 172.9251 \\
\hline 15 & Bosnia \& Herzegovina & 219.5312 & 11.93276 & 213.1658 \\
\hline 16 & Botswana & 246.8945 & 12.2511 & 237.9227 \\
\hline 17 & Brazil & 43.87928 & 8.234073 & 28.6998 \\
\hline 18 & Brunei & 221.0192 & 15.92977 & 232.9577 \\
\hline 19 & Bulgaria & 55.06635 & 15.85517 & 18.04503 \\
\hline
\end{tabular}




\begin{tabular}{|c|c|c|c|c|}
\hline 20 & Cambodia & 30.12426 & 11.87197 & 44.89358 \\
\hline 21 & Cameroon & 20.15004 & 10.00824 & 2.015692 \\
\hline 22 & Canada & 103.5157 & 15.75209 & 62.67028 \\
\hline 23 & $\begin{array}{l}\text { Central African } \\
\text { Republic }\end{array}$ & 289.8097 & 11.34084 & 268.1712 \\
\hline 24 & Chad & 170.8293 & 8.470464 & 157.0955 \\
\hline 25 & Chile & 40.06443 & 14.65458 & 8.975959 \\
\hline 26 & China & 135.6989 & 15.09346 & 91.14995 \\
\hline 27 & Colombia & 22.69762 & 12.316 & 41.70231 \\
\hline 28 & Congo, Dem. Rep. & 131.7259 & 14.05193 & 141.1647 \\
\hline 29 & Costa Rica & 134.1644 & 15.68286 & 148.808 \\
\hline 30 & Cote d'Ivoire & 30.14849 & 12.65065 & 10.61758 \\
\hline 31 & Croatia & 7.755126 & 15.19682 & 38.77003 \\
\hline 32 & Cyprus & 1.809173 & 13.93 & 28.43452 \\
\hline 33 & Czech Republic & 74.13995 & 16.39069 & 32.77892 \\
\hline 34 & Denmark & 92.54745 & 16.42656 & 50.64097 \\
\hline 35 & Dominican Republic & 132.8231 & 11.93116 & 129.5722 \\
\hline 36 & Ecuador & 154.1961 & 8.705811 & 145.4323 \\
\hline 37 & Egypt, Arab Rep. & 88.5852 & 8.261001 & 65.58367 \\
\hline 38 & El Salvador & 171.0084 & 12.79722 & 185.3572 \\
\hline 39 & Equatorial Guinea & 283.4711 & 4.531311 & 229.7646 \\
\hline 40 & Estonia & 111.2522 & 17.17595 & 12.8197 \\
\hline 41 & Ethiopia(excludes & 262.2342 & 12.6457 & 30.85875 \\
\hline
\end{tabular}




\begin{tabular}{|c|c|c|c|c|}
\hline & Eritrea) & & & \\
\hline 42 & Fiji & 187.5156 & 11.39253 & 183.1019 \\
\hline 43 & Finland & 72.22315 & 17.19917 & 32.58974 \\
\hline 44 & Fm Sudan & 11.39783 & 13.34881 & 27.03333 \\
\hline 45 & France & 112.5371 & 17.26116 & 66.15956 \\
\hline 46 & Gambia, The & 51.27029 & 9.680306 & 69.07072 \\
\hline 47 & Georgia & 110.9839 & 15.46065 & 133.7284 \\
\hline 48 & Germany & 129.5032 & 16.55592 & 81.97908 \\
\hline 49 & Ghana & 63.49084 & 10.93046 & 74.7203 \\
\hline 50 & Greece & 59.93231 & 16.62796 & 22.62067 \\
\hline 51 & Guatemala & 23.89782 & 15.43757 & 12.86194 \\
\hline 52 & Guyana & 62.44444 & 13.70168 & 82.27827 \\
\hline 53 & Honduras & 99.45846 & 11.41414 & 103.2714 \\
\hline 54 & Hong Kong, China & 127.5505 & 17.64396 & 80.38369 \\
\hline 55 & Hungary & 67.41123 & 16.67598 & 21.41722 \\
\hline 56 & Iceland & 199.2309 & 15.22367 & 219.0957 \\
\hline 57 & India & 111.6653 & 13.48805 & 91.29868 \\
\hline 58 & Indonesia & 101.4218 & 12.67899 & 66.04922 \\
\hline 59 & Iran, Islamic Rep. & 107.7059 & 6.257303 & 85.92795 \\
\hline 60 & Ireland & 62.43083 & 17.1217 & 23.45911 \\
\hline 61 & Italy & 121.2416 & 16.75755 & 75.42147 \\
\hline 62 & Jamaica & 236.5981 & 10.08747 & 221.9319 \\
\hline 63 & Japan & 83.35216 & 15.07451 & 48.75778 \\
\hline
\end{tabular}




\begin{tabular}{|c|c|c|c|c|}
\hline 64 & Jordan & 74.16801 & 11.73383 & 44.47097 \\
\hline 65 & Kazakhstan & 10.3447 & 15.19504 & 36.78124 \\
\hline 66 & Kenya & 144.6941 & 10.15553 & 110.1769 \\
\hline 67 & Korea, Rep. & 109.4884 & 11.4211 & 77.07384 \\
\hline 68 & Kuwait & 124.1321 & 15.32291 & 82.34724 \\
\hline 69 & Kyrgyz Republic & 114.403 & 17.03849 & 141.9144 \\
\hline 70 & Lao PDR & 203.8572 & 11.86205 & 158.7626 \\
\hline 71 & Latvia & 50.83404 & 17.63621 & 9.556703 \\
\hline 72 & Lebanon & 42.88956 & 13.07734 & 12.32561 \\
\hline 73 & Lesotho & 32.24658 & 4.981373 & 44.18729 \\
\hline 74 & Liberia & 99.26674 & 13.20974 & 119.5004 \\
\hline 75 & Lithuania & 64.10288 & 17.63459 & 22.18313 \\
\hline 76 & Luxembourg & 70.05161 & 16.96549 & 99.11766 \\
\hline 77 & Macedonia, FYR & 232.8615 & 9.880139 & 171.276 \\
\hline 78 & Madagascar & 67.00026 & 13.90809 & 32.85418 \\
\hline 79 & Malawi & 48.30541 & 11.31043 & 62.59064 \\
\hline 80 & Malaysia & 145.4649 & 13.93964 & 98.49519 \\
\hline 81 & Mali & 87.903 & 11.44639 & 94.87375 \\
\hline 82 & Malta & 55.49247 & 15.6491 & 98.45648 \\
\hline 83 & Mauritania & 75.04427 & 12.75841 & 92.15166 \\
\hline 84 & Mauritius & 16.86516 & 14.88312 & 51.21461 \\
\hline 85 & Mexico & 23.76974 & 10.52735 & 3.613805 \\
\hline 86 & Moldova & 172.9585 & 15.704 & 188.6881 \\
\hline
\end{tabular}




\begin{tabular}{|c|c|c|c|c|}
\hline 87 & Mongolia & 429.6747 & 18.26865 & 450.5825 \\
\hline 88 & Morocco & 80.46984 & 5.812117 & 63.60097 \\
\hline 89 & Mozambique & 37.24347 & 14.17821 & 5.541503 \\
\hline 90 & Myanmar & 35.07677 & 15.79248 & 52.40344 \\
\hline 91 & Namibia & 161.1358 & 8.106598 & 154.1157 \\
\hline 92 & Nepal & 75.53462 & 12.6579 & 89.60019 \\
\hline 93 & Netherlands & 49.07908 & 17.44328 & 72.19784 \\
\hline 94 & New Zealand & 48.75278 & 15.62556 & 20.66587 \\
\hline 95 & Nicaragua & 44.09157 & 11.20112 & 149.1953 \\
\hline 96 & Niger & 128.0102 & 13.69624 & 143.7887 \\
\hline 97 & Nigeria & 65.19015 & 10.47253 & 72.69235 \\
\hline 98 & Norway & 24.40927 & 16.59685 & 10.53053 \\
\hline 99 & Oman & 128.399 & 14.79186 & 87.83453 \\
\hline 100 & Panama & 138.05 & 14.8639 & 152.6679 \\
\hline 101 & Papua New Guinea & 127.3184 & 12.51638 & 135.2955 \\
\hline 102 & Paraguay & 57.2059 & 11.37564 & 68.66883 \\
\hline 103 & Peru & 37.00884 & 14.77176 & 62.01264 \\
\hline 104 & Philippines & 58.36716 & 12.2372 & 30.5056 \\
\hline 105 & Poland & 53.16713 & 16.0553 & 27.54976 \\
\hline 106 & Portugal & 76.16298 & 16.90272 & 35.02916 \\
\hline 107 & Qatar & 85.84266 & 15.49042 & 47.93848 \\
\hline 108 & Romania & 34.50641 & 14.23393 & 3.212794 \\
\hline 109 & Russian Federation & 67.62364 & 13.54558 & 35.09664 \\
\hline
\end{tabular}




\begin{tabular}{|c|c|c|c|c|}
\hline 110 & Rwanda & 210.9273 & 9.291923 & 189.4062 \\
\hline 111 & Saudi Arabia & 140.3432 & 15.32784 & 96.60952 \\
\hline 112 & Senegal & 23.43875 & 12.49615 & 42.59416 \\
\hline 113 & Singapore & 26.94141 & 18.12101 & 13.56459 \\
\hline 114 & Slovak Republic & 137.5779 & 16.49875 & 145.6775 \\
\hline 115 & Slovenia & 64.55243 & 16.04065 & 27.64119 \\
\hline 116 & South Africa & 99.08988 & 9.456853 & 71.81931 \\
\hline 117 & Spain & 104.4527 & 17.46274 & 58.69412 \\
\hline 118 & Sri Lanka & 127.583 & 13.57841 & 95.1024 \\
\hline 119 & Suriname & 214.339 & 14.71343 & 264.3925 \\
\hline 120 & Swaziland & 223.1364 & 9.759436 & 211.1951 \\
\hline 121 & Sweden & 99.86397 & 17.20477 & 57.44289 \\
\hline 122 & Switzerland & 69.60507 & 15.4427 & 35.07791 \\
\hline 123 & Syrian Arab Republic & 7.430358 & 11.09519 & 90.99744 \\
\hline 124 & Tajikistan & 35.34986 & 14.27209 & 49.86606 \\
\hline 125 & Tanzania & 67.88499 & 13.37981 & 33.60601 \\
\hline 126 & Thailand & 101.9763 & 9.29075 & 82.69406 \\
\hline 127 & Togo & 43.72618 & 10.79163 & 10.84155 \\
\hline 128 & Trinidad and Tobago & 156.6664 & 11.42131 & 148.2195 \\
\hline 129 & Tunisia & 23.24994 & 3.975042 & 19.34926 \\
\hline 130 & Turkey & 100.4113 & 15.35926 & 62.06182 \\
\hline 131 & Uganda & 59.41723 & 13.09084 & 77.71328 \\
\hline 132 & Ukraine & 94.20039 & 14.69071 & 55.81731 \\
\hline
\end{tabular}




\begin{tabular}{|c|l|c|c|c|}
\hline 133 & United Arab Emirates & 165.7166 & 1.618697 & 122.0264 \\
\hline 134 & United Kingdom & 138.6357 & 16.23023 & 97.12645 \\
\hline 135 & United States & 130.2779 & 13.94394 & 87.18809 \\
\hline 136 & Uruguay & 13.56985 & 11.10848 & 30.73179 \\
\hline 137 & Uzbekistan & 30.5403 & 13.9219 & 78.74199 \\
\hline 138 & Vietnam & 19.52577 & 9.577114 & 4.557747 \\
\hline 139 & Yemen & 27.07306 & 15.36824 & 1.843161 \\
\hline 140 & Zambia & 68.79035 & 12.19625 & 88.23256 \\
\hline 141 & Zimbabwe & 75.29946 & 9.720767 & 86.41676 \\
\hline
\end{tabular}

